Article

\title{
Exploring the Benefits of Small Catchments on Rural Spatial Governance in Wuling Mountain Area, China
}

\author{
Jie Qiao ${ }^{1} \mathbb{D}$, Mike Crang ${ }^{2}$, Liangping Hong ${ }^{1, *}$ and Xiaofeng $\mathrm{Li}^{1}$ \\ 1 School of Architecture and Urban Planning, Huazhong University of Science and Technology, Wuhan 430074, \\ China; jie_qiao@hust.edu.cn (J.Q.); lixf@hust.edu.cn (X.L.) \\ 2 Department of Geography, Durham University, Science Site, South Road, Durham DH1 3LE, UK; \\ m.a.crang@durham.ac.uk \\ * Correspondence: h_liangping@hust.edu
}

Citation: Qiao, J.; Crang, M.; Hong, L.; Li, X. Exploring the Benefits of Small Catchments on Rural Spatial Governance in Wuling Mountain Area, China. Sustainability 2021, 13, 760. https://doi.org/10.3390/ su13020760

Received: 30 November 2020 Accepted: 29 December 2020 Published: 14 January 2021

Publisher's Note: MDPI stays neutral with regard to jurisdictional clai$\mathrm{ms}$ in published maps and institutional affiliations.

Copyright: (C) 2021 by the authors. Licensee MDPI, Basel, Switzerland. This article is an open access article distributed under the terms and conditions of the Creative Commons Attribution (CC BY) license (https:// creativecommons.org/licenses/by/ $4.0 /)$.

\begin{abstract}
China is facing an important period of rural governance innovation and restructuring of territorial spatial patterns. This paper selects catchments as the most closely related spatial units for rural industrial development and rural settlement activities, profoundly revealing the characteristics of transformational development and spatial governance in mountainous areas. To date, extensive literature in this area has produced a broad multidisciplinary consensus on catchment water and soil conservation and rural industry development; however, the interactive mechanism of ecological, social, and economic networks, and the characteristics behind small catchments which benefit from spatial governance, have never been analyzed and are relatively new to the sphere of rural governance. Our research argues the relative importance of multi-scale catchment units compared with traditional administrative village units in enhancing the organizational benefits of rural revitalization in terms of workforce, resources, and capital, using the case study of a catchment in the Wuling mountainous area. Our study presents a framework to explore the multi-dimensional governance experience of a small catchment in the Wuling mountainous area and proposes to integrate the resource endowment advantages of small catchments into rural industries development and transform the economic and social benefits contained in the ecological environment into multi-scale spatial benefits among farmers, villages, and the regional rural area. However, not all cases provide positive evidence. The overall development of a catchment is confronted with complex constraints, which are mainly related to the development stage and local historical and geographical factors. Furthermore, affected by the top-down "project-system" in the "poverty era", the logic of "betting on the strong" and the single-centered logic of resource allocation at the grassroots level exacerbated the fragmentation of the mountainous area. Generally speaking, the catchment perspective promotes regional linkage development and multi-center governance modes and triggers multidisciplinary theoretical thinking to some extent. The catchment's overall development helps play to the comparative advantage of mountainous areas and promotes endogenous sustainable development to a certain degree. However, the promotion of catchment governance in poverty-stricken mountainous areas is faced with a lack of financial foundation and needs support in order to break through the national system and local social constraints.
\end{abstract}

Keywords: China; spatial governance; small catchment; Wuling mountain area

\section{Introduction}

The difficult progress of mountainous development is universally recognized as largely arising from natural limitations, economic bottlenecks, and social, local, and political constraints [1]. The core challenge is dealing with the disagreement of various conceptual dimensions under a controversial management system and promoting governance as the coupling unit of a decision design and the implementing space unit [2]; the term "controversial management system" mainly refers to the contradiction between the 
top-down administrative unit and the overall development of the ecological resources of the mountain area. In Global South countries, policies for rural areas aim to contribute to recognizing and making use of strengths and opportunities [3]. Scholars and policymakers proposed developing a strategic framework for mountainous areas, considering the importance of mountain farming, the high levels of biodiversity, and the scattered and low density populations in these areas. These frameworks should be more flexible in multi-level governance arrangements [4]. Governance always takes place in a particular time and space, and the spatial scope and scale determine the difficulty and complexity of governance issues and governance relationships, thus affecting the method and effect of governance [5]. Governance constraints are the main reason for the slow development of mountain areas, especially in developing countries and impoverished areas [6]. China is a mountainous country, with mountainous areas taking up two-thirds of the total national area [7]. A catchment, as a composite unit with the main elements of ecology, society, and economy, is equipped with an innovative approach to land management, public service provision, and local governance organization units for mountainous development in an innovative and sustainable way $[8,9]$. While a complex web of overlapping political jurisdictions is present in catchment land and water management, most decision-making occurs at the local level of township, city, or village. These local decision-making bodies typically lack the information and jurisdictional authority to influence upstream and downstream events [10]. Small catchments are the most closely related regional living units between humans and the environment in mountainous areas. They have multi-scale and natural randomness characteristics, reflecting the comprehensive relationship between mountain natural geography, local society, and spatial governance. Focusing on a small catchment area as the research object helps to understand the driving force behind the development of a complex environment in mountainous areas and formulate effective strategies for rural industry prosperity and ecological livability.

Under the top-down governance framework of the Chinese government, traditional rural spatial governance research is mostly focused on the construction of rural settlements under administrative units and has a weak understanding of the ecological, social, and economic logic behind the rural settlement system. Since the late twentieth century, rural China has experienced a rapid and far-reaching reshaping of social and economic structures. These processes present a number of challenges to the rural areas which have been confronted with territorial spatial pattern restructuring, including changes in demographic structures, employment opportunities, community organization, lifestyles and standards of living, accessibility, and rural culture as well as the restructuring of rural industries [11-13]. There are fundamental and significant spatial variations in the experience and impact of these changes in rural China, especially for mountainous areas [14]. Existing studies have pointed out that understanding the social, economic, and political landscape involved in small catchments is essential for understanding the ecological environment and socioeconomic changes in rural areas and promoting local policy design and management decisions [15].

Thoroughly revealing the mechanism of interaction between the industrial layout of small catchments and rural settlements in mountainous areas is a problem that needs to be solved urgently. The subject of human settlement environment science is important in China for the implementation of rural revitalization strategy. The objective of this paper is to address: (1) Why analysis of the discourse system of spatial rural governance in mountainous areas is important, from the perspective of a small catchment. (2) What are the practical dilemmas of spatial governance in a catchment facing rural transformation and development? (3) How do resource endowments and the environmental characteristics of the catchment affect rural revitalization and generate spatial governance benefits, and what are these benefits?

This paper selects the Changyang Tujia Autonomous County in the Wuling mountain area of western Hubei as the sample area, analyzes the practical difficulties faced by promoting the spatial governance of a small catchment in a rural mountainous area, and 
reveals the ecological, social, and governance logic behind the governance constraints. Combined with the investigation and demonstration of typical cases in the sample area, this paper summarizes the local experience from the three aspects of resource endowment structure, vertical spatial productivity, and multi-center governance structure, and explores the benefits of small catchments for sustainable spatial governance according to local conditions.

\section{Materials and Methods}

\subsection{Context of Catchment in Mountainous China}

A catchment is an ecological, social, and cultural systemic "structure" that is gradually formed in the process of rural spatial production based on hydrological natural ecological entities. As a typical economic geographical unit of mountainous areas, the coupling relationship between mountain element layout and spatial structure, with catchment as the carrier, is of great significance to the transformation of mountain industry development [16], which provides material carriers for the protection of mountain ecological and cultural resources [17]. Small catchments are typical rural human ecological units in mountainous areas, and a complex system is formed by the interaction of "ecological units" and "settlement units" [18], reflecting the comprehensive relationship among regional ecological environment, social resource conditions, and economic system structure (Figure 1). It has the characteristics of multi-scale and natural randomness, reflecting the unification process of mountainous land, space, scale, structure, function, and elements [19]. As a composite management unit of the mountainous area, small catchments are often divided by different administrative regions or ownership boundaries. Thus, transboundary is the essence of catchment governance [20].

From the perspective of catchment ecosystems, different natural village ecosystems serve as the unified features of subsystems, coordinating with each other according to differences in population, land terrain, and other resource endowments within the catchment, and mutually restrict and complement each other, forming a symbiotic relationship. This symbiotic relationship is manifested as the interests of horizontal village development which are closely related, and vertical spatial resources interact and complement each other within the catchment. For example, the vertical "Eco-economic system under threedimensional climate" resource system of the catchment provides support for optimizing the industrial spatial layout system [21]. The advantages of the horizontal "catchment economy" in mountainous areas are conducive to linking isolated geographical units to form rural industrial belts, promoting a flow combination of industrial factors, and driving regional economic development [22]. Meanwhile, understanding the rural ecosystems in different geomorphological areas has great practical significance for improving rural ecological environment, increasing land productivity, and formulating scientific rural development [23].

Land "fragmentation" in mountainous areas is particularly prominent; it is necessary to reform and adjust the governance structure and find the root cause through ecological problems to achieve holistic governance. The publicity of the catchment's ecological environment has led the local government to take the leading position in establishing and improving the legal responsibility mechanism of rural environmental supervision [24]. Due to differences in geographical conditions, resource endowment, and governance capacity, small catchment development is mutually coordinated and restricted, forming an interdependent symbiotic relationship. Promoting the spatial governance of a small catchment can promote the coupling of social-economic systems and natural ecosystems on the basis of ecological protection, and enhance the overall "social and economic" benefits [25]. Relevant studies have proved that in areas with less land and more people, a relatively equal distribution of land rights is conducive to improving the efficiency of agricultural management and alleviating poverty [26]. In addition, some of the literature in turn indicates that exploring the development law of different habitat ecological units in mountainous areas 
and grasping the overall effect of resources in mountainous areas can help overcome the "crowding out" effect of economy-oriented development on vulnerable groups [27].

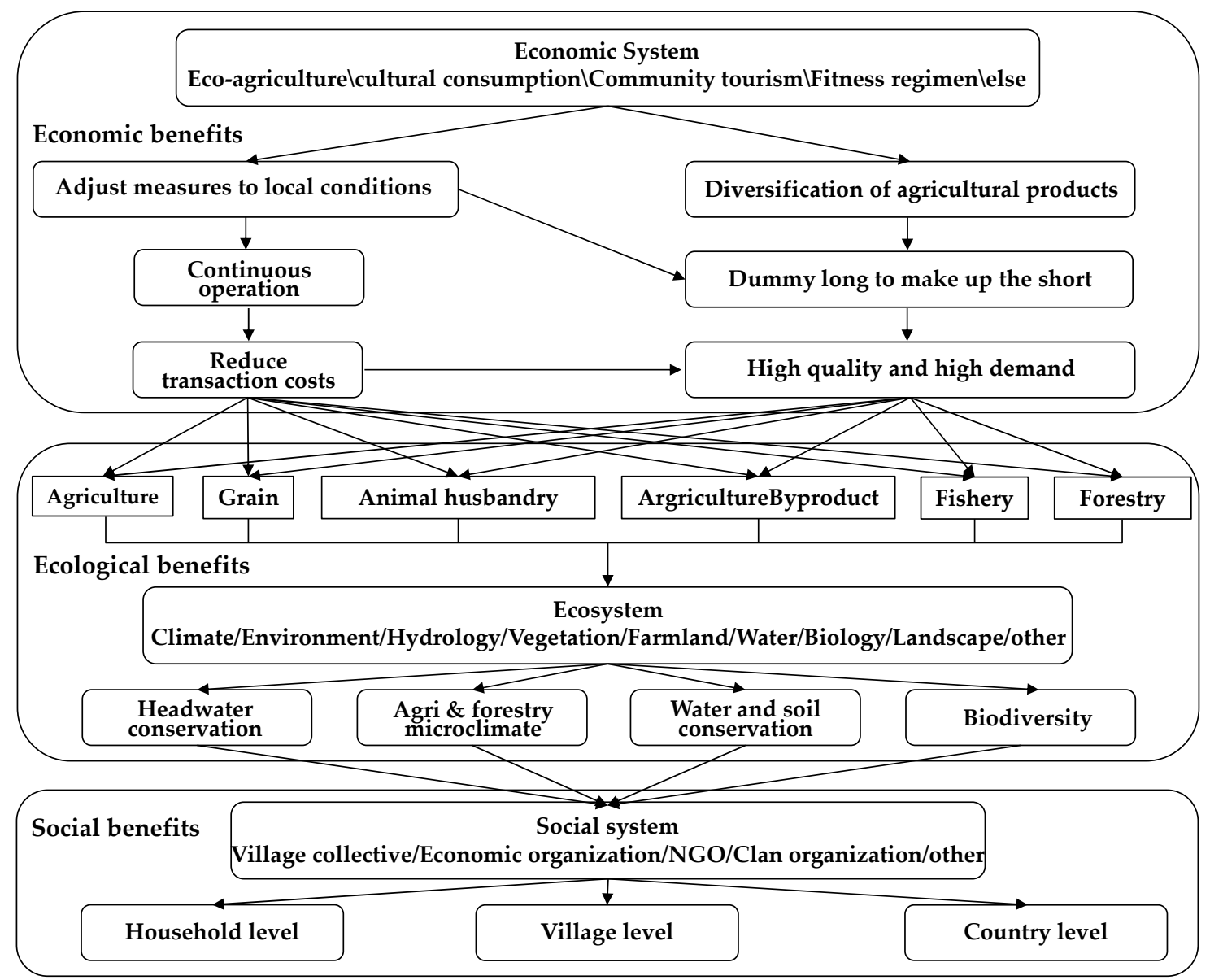

Figure 1. The characteristics of a multiple dimension system in a catchment and overall benefit analysis framework. Figure source: drawn by authors.

\subsection{Research Area}

The Wuling Mountain Area (WMA) is the largest inhabited trans-provincial area of ethnic minorities in China, which comprises an important ecological barrier in the middle reaches of the Yangtze River and a core hinterland for promoting ethnic rural revitalization $[28,29]$. It is also where many important regional rivers begin, along with their main streams and tributaries [30]. The WMA of western Hubei is the source and flowing place of the Qingjiang River, a tributary of the Yangtze River (Figure 2). The region covers an area of 29,900 square kilometers, including ten ethnic counties (cities), with a total population of 4.847 million, which is mainly distributed in more than 680 small rural catchments areas of different scales (Figure 3). Small catchments are the basic units of mountainous industrial development and rural settlement activities, and shoulder the dual tasks of regional ecological protection and rural revitalization in the WMA.

We chose Changyang Tujia Autonomous County (CTAC), which is located in the northeast of the WMA, in the middle and lower reaches of the Qingjiang river. CTAC covers an area of 3430 square kilometers including 154 administrative villages, which are distributed separately in eleven townships. CTAC is one of the national-level poverty-stricken counties and also the model county for all-for-one tourism of Hubei Province (CTAC was removed from the poverty list in April 2020). By the end of 2019, the total population of CTAC was 385,900 people, with 967 villages and 152.8 thousand households; there were still 
81,184 poor people in Changyang County [31]. The selected cases are situated in a forked tributary extending in the middle and lower reaches of Qingjiang river, a tributary of the Yangtze River. In the WMA, the fragmentation of the industrial layout and the organization of human settlements have aggravated the organizational dilemma of manpower, resources, and capital in the revitalization of rural industries $[32,33]$, resulting in damage to the rural regional functional system and environment. This destruction has seriously affected the ecological security pattern of mountainous areas and the comprehensive benefits of rural industrial revitalization.

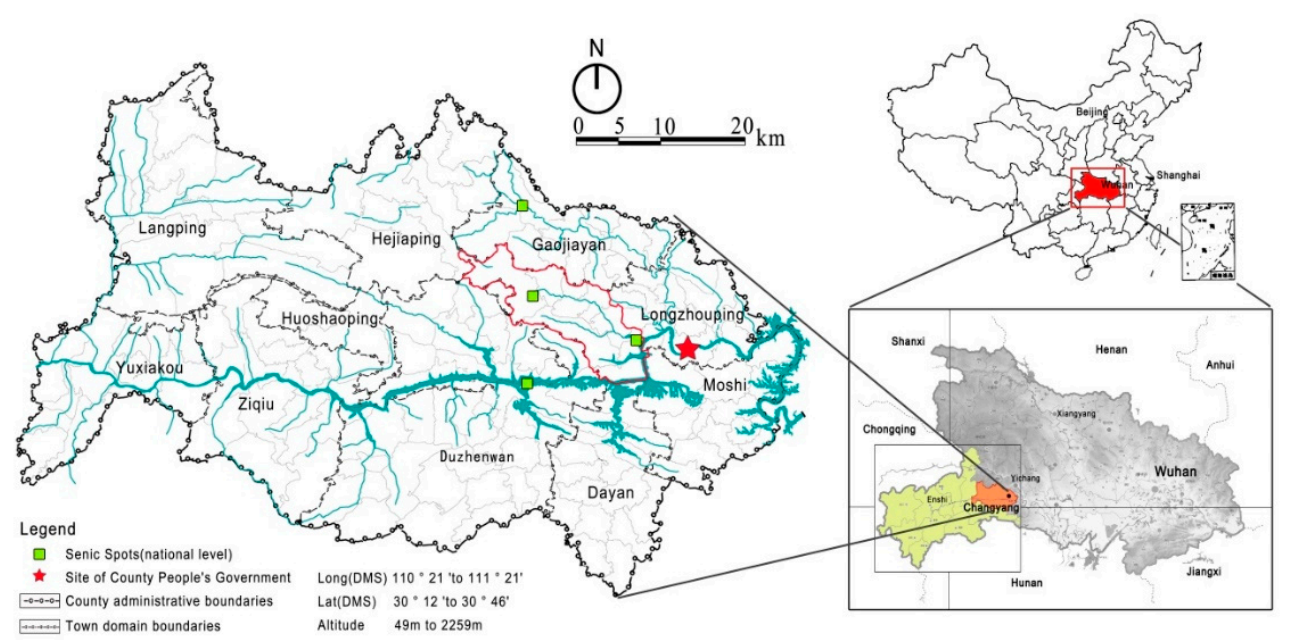

Figure 2. Case location in China. Figure source: reproduced by authors.

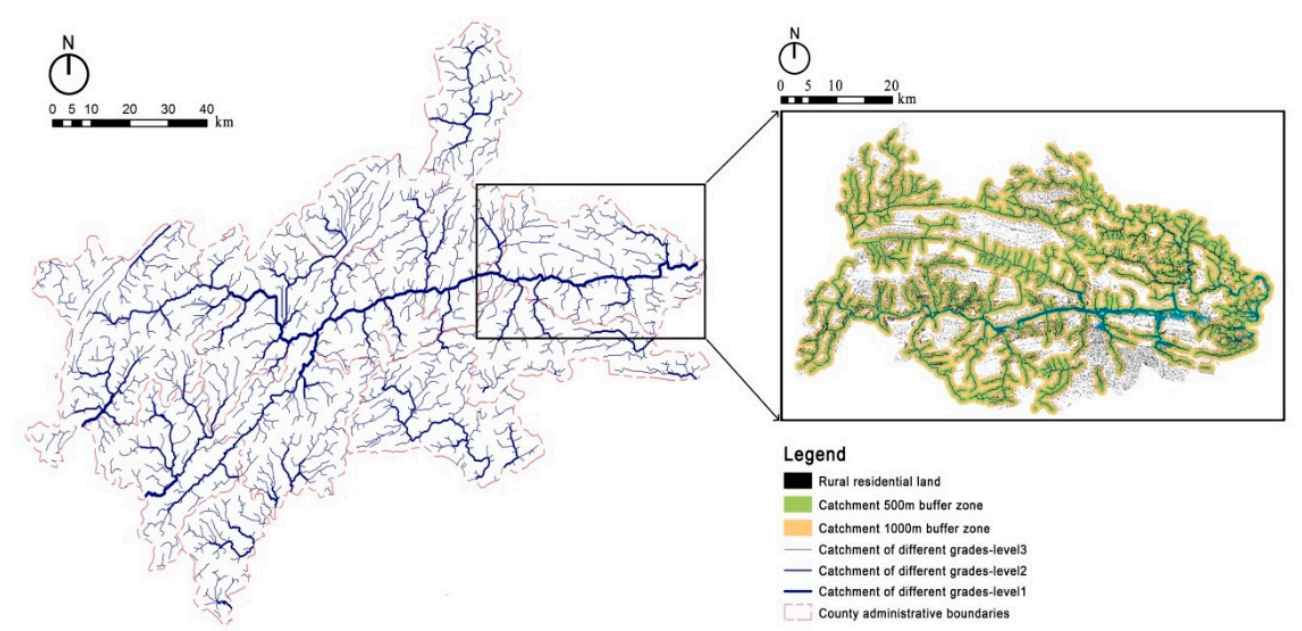

Figure 3. The Wuling Mountain Area (WMA) of Western Hubei, China and its hydrological characteristics. Figure source: drawn by authors based on DEM (Digital Elevation Model) image data and the second county territorial space survey data.

\subsection{Date and Method}

The evidence in this paper is derived from fieldwork conducted during the pro-poor tourism pilot project of Hubei province which lasted for three years, from January 2015 to December 2018. Before we selected the 15 typical catchment cases as the focus of our attention from 85 catchments across the county (see Figure 3), we finished the multi-geographic spatial survey of CTAC (Table 1). Firstly, we analyzed and clarified the significance of spatial governance in a small catchment of the county. Secondly, the local governments agreed to promote the overall development of the small catchment area, as the current problems of single-center governance in mountainous rural areas are bottlenecks that need to be overcome, especially when facing "all-for-one" tourism ("all-for-one tourism" is a 
Chinese term, as a new development strategy put forward by the Chinese government in 2018, which calls for promoting the development of tourism regionally, tourism supply quality, tourism management standardization, and tourism benefit maximization. See more from: http://english.www.gov.cn/statecouncil/ministries/202012/20/content_WS5 fdf084fc6d0f725769422f3.html) development and the implementation of rural revitalization strategy. Lastly, the selected typical samples had to reflect the characteristics of the ecological space of rural settlements in the county and the core issues facing catchment governance. The contiguous development of small catchments along the front line involves multi-level spatial governance issues such as a tourism-oriented development layout and settlement relocation; ecological environment protection and agricultural industry development; anti-fragmentation governance and rural public goods supply. It faces the dual problems of resource development and ecological governance. We conducted field surveys in the process of compiling the pro-poor tourism development plansof in the two small catchment of CTAC_-Yantouxi(YTX) and Moshi(MS). During the following years, with the promulgation of the plan and the implementation of the project, we also launched three follow-up investigations, focusing on the improvement of the rural settlement environment, the implementation of rural industrial projects, and public participation in public affairs, etc. Since the compilation process of rural planning is responsible for coordinating and implementing the relevant work of the administrative departments at all levels, our field surveys have not only been obtained by the county people's government, but also have been supported by the county's land and resource, hydrological, finance, and tourism and cultural bureaus. At the same time, with strong political support, we can gain the trust of rural actors as soon as possible and grasp the sensitive issues and important resource allocation logic in grassroots governance. Apart from ledger data and vector data, the main data of this paper are collected from interviews. Such as in the YTX catchment, we set up the availability of personal connections with local officials-village cadres-which is important as it helps us to conduct fieldwork in different villages rather than just in the "model villages". Our fieldwork covers seven administrative villages along the YTX catchment, including fifty-five smaller natural villages, with 5071 households and involving a total of 16,920 people. During this process, we had twelve meetings at county, town, and village governance levels; 812 valid questionnaires were conducted in the form of structured interviews and semi-structured interviews with thirty-two villagers, including those living in poverty, the common households, elites, eighteen cadres, four enterprise representatives, and eight county officers from different departments (Table 1). To adapt to the seasonal flow of the rural population and the characteristics of daily life in these areas, the surveys were distributed in different seasons and mainly based on a village residency survey, which increased the diversity and authenticity of the subjects we interviewed.

Table 1. Multi-scale transboundary characteristics of small catchments in CTAC.

\begin{tabular}{cccc}
\hline No. & $\begin{array}{c}\text { Name of Small } \\
\text { Catchments }\end{array}$ & $\begin{array}{c}\text { Number } \\
\text { of Joined Towns }\end{array}$ & $\begin{array}{c}\text { Number } \\
\text { of Joined Villages }\end{array}$ \\
\hline 1 & Yachahe & 3 & 14 \\
2 & Liuping & 3 & 6 \\
3 & Qianzhangkeng & 1 & 4 \\
4 & Tianchikou & 1 & 4 \\
5 & Yangsongping & 1 & 3 \\
6 & Xiaoxi & 2 & 15 \\
7 & Xiaomaxi & 2 & 7 \\
8 & Muqiaoxi & 3 & 26 \\
9 & Zhituoping & 1 & 3 \\
10 & Yantouxi & 1 & 7 \\
12 & Linxiangxi & 2 & 4 \\
13 & Qingjiang & 8 & 44 \\
14 & Moshi & 1 & 9 \\
\hline
\end{tabular}




\section{Dilemma of Rural Spatial Governance in WMA}

\subsection{Rural Settlement Space Restructuring under Ecological Constraints}

The mountainous areas are mostly resource-rich and ecologically sensitive. How to avoid the traditional path of "grow first, clean up later" is an urgent need to promote the improvement of the endowment structure of ecological resources in the process of spatial reorganization [34]. At present, most of the poverty alleviation strategies in the WMA are based on the needs of rural tourism for the adjustment of the industrial structure [27]. In contrast, insufficient attention has been paid to the characteristics of the resource system in ecological human settlements. Taking CTAC as an example, the county's forest coverage rate has reached $70.1 \%$; however, most of the exploitation and utilization of ecological environment resources are distributed linearly along the Qingjiang axis in the east-west direction. The ecological spatial structure of multi-scale catchments has a significant impact on the spatial organization of rural settlements in the county (see Figure 4). The density of rural residential areas in CTAC is closely related to the Qingiiang river and its tributaries. Through analysis of the correlation between county settlements and water systems, it is found that $56 \%$ of Changyang County's rural settlements (data from 2018, 54\% in 2014) are distributed within $500 \mathrm{~m}$ on both sides of eighty-five catchments of uneven size within the CATC (see Figure 5); the population density of the villages along the catchment is significantly higher than that of other areas. The average area of the villages on both sides of the Qingjiang River is greater than two hundred inhabitants per square kilometer. In addition, it is found that the agglomeration of industrial elements and the development of tourism resources are the main reasons for the agglomeration of rural settlements in the county. Due to the restrictions on regional urbanization and mountain traffic conditions, the transaction costs of rural industrial resource elements (such as farmland, woodland, homesteads, etc.) are high. In order to reduce transaction costs, market- and governmentled resource development often present point-like agglomeration characteristics, such as Kouzi villages, Kouzhi towns, or water and land transportation nodes in the catchment, leading to structural imbalances in the reorganization of rural settlements. In addition, although the regional traffic pattern in the WMA has been greatly improved since 2014, rural infrastructure and public services are still unbalanced due to the impact of the gradient economy in the mountainous area, and the local spatial polarization effect is obvious. There are prominent contradictions in rural settlements, especially around large tourist attractions and national highways. On the whole, due to the long-term impact of geographical poverty and ecological protection policies, the economy of mountainous counties is still dominated by traditional agricultural cultivation, with a large proportion of primary production and a high proportion of agricultural population (the actual urbanization rate of CTAC is only $37 \%$ in 2018).

Facing the drive of the State Council's rural revitalization strategy, the WMA in western Hubei has obvious late-mover advantages, especially in the regional background of rural industrial transformation driven by urbanization and rural tourism. However, due to the long return period of economic investment in rural tourism, high market transaction costs, and poor financial foundations in mountainous counties, most rural tourism projects can easily engage in the rent-seeking behaviors of market capital on rural land in disguise. At the same time, the risks of tourism development failing or market capital withdrawal, etc., would quickly cause the deterioration of the relationship between humans and land, which would have an irreversible impact on the transformation of mountain rural industries and the functional improvement of the ecological human settlements unit. 


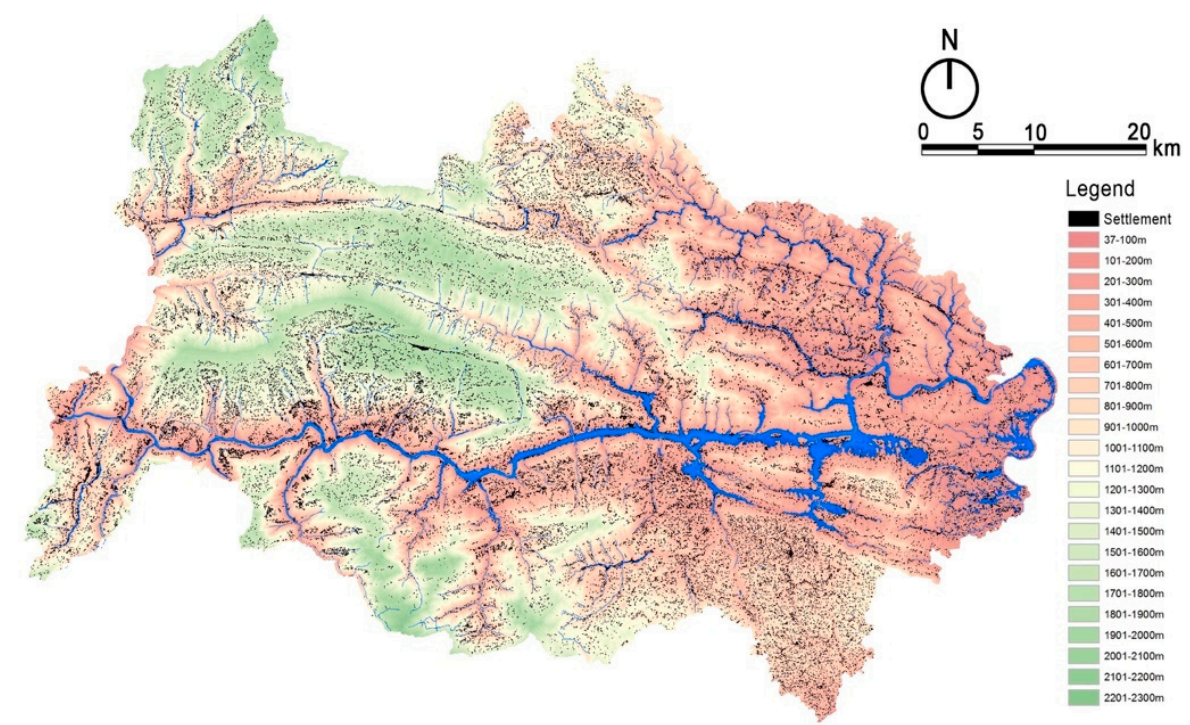

Figure 4. Settlement and ecological spatial pattern in Changyang county. Figure source: according to CTAC third land space survey (2019) data and elaborated by authors.

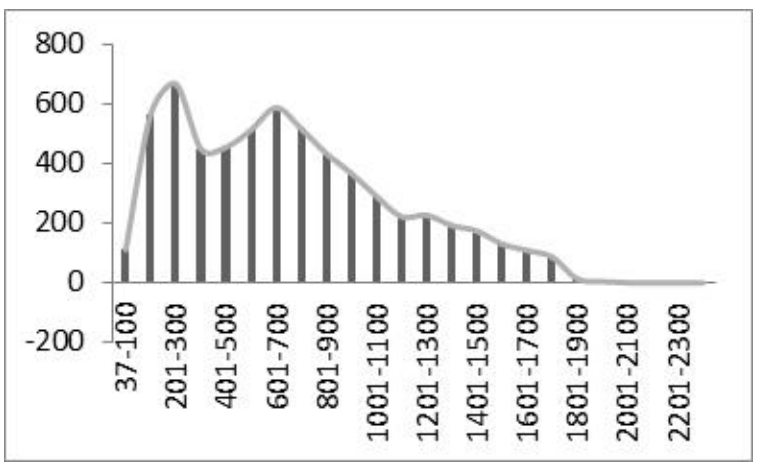

Figure 5. The Elevation distribution of settlements in CTAC. Note: Ordinate (HA), abscissa (M). Figure source: according to CTAC third land space survey (2019) data and elaborated by authors.

\subsection{Separation from Market and Society Caused by Traffic Bottleneck}

The essence of the difficult development progress in the WMA is that the high transaction cost caused by the traffic bottleneck restricts the market and social conditions needed for the development of mountainous areas, and hinders the effective transformation of "resources, assets, funds". In the early stages of industrialization of the WMA, it was a common choice for the local government and village committee to compensate for the weak supply of rural public goods at the expense of ecological and environmental costs. Before 2014, CTAC had not yet integrated into the regional transportation network. The mining industry-oriented development model based on investment in heavy industrial assets dominates the construction of infrastructure in rural development. The development of industrial and mining enterprises has promoted the improvement of transportation infrastructure and the employment level of rural labor. Furthermore, it has also increased the burden of ecological governance and the difficulty of poverty alleviation in small catchments. At present, the overall transportation infrastructure conditions of the WMA lag behind the development needs of industrialization and agricultural modernization [35]. The separation of market and society under the traffic bottleneck is an important factor affecting rural development. The specific manifestations are as follows: (1) The transformation of resources into asset value in the WMA is restricted by traffic conditions, and traffic factors have become an important factor in determining how family welfare develops over time. Through GIS (Geo-Information system) analysis of the road buffer zone in the small 
catchment (Figure 6), there are 410 poor households in YTX mainly gathered outside the one-hundred-fifty meters buffer zone of the backroad or the two-hundred meters buffer zone of the rural roads, accounting for $52.9 \%$ of the total poverty households (Table 2). The reason is that traffic conditions have an important impact on the livelihood choices and flow of poor households by affecting the development of land resources in small catchments, the improvement of housing quality and drinking water conditions, and the change of family structures. (2) The rural spatial organization and spatial governance of small catchments are mainly affected by the traffic structure. For example, traffic accessibility directly affects the scale of village land management, capital access conditions, and the foundation of social organization. The survey found that poverty-causing factors and physical geographic factors (elevation, slope, topography, etc.) are more accidentally related on the micro-scale, but are highly related to the effective use of cultivated land. Through spatial overlay analysis of geographical factors such as the geographic location, elevation, and slope of poor households in mountainous areas, the study found that the incidences of poverty tend to show a decreasing spatial characteristic of "high mountain area, middle mountain area, valley area"; moreover, the incidences of poverty will be higher in settlements with less than twenty households. In summary, the smaller the scale of agglomeration, the lower the transportation access rate, the more obvious the characteristics of separation between the market and the society, and the higher the transaction cost of the supply of public goods and the entry of social capital. If it is easy to find places with more traffic congestion, the higher the probability of farmers' land abandonment and the lower the utilization efficiency of land resources, which ultimately leads to an increase in the incidence of poverty.

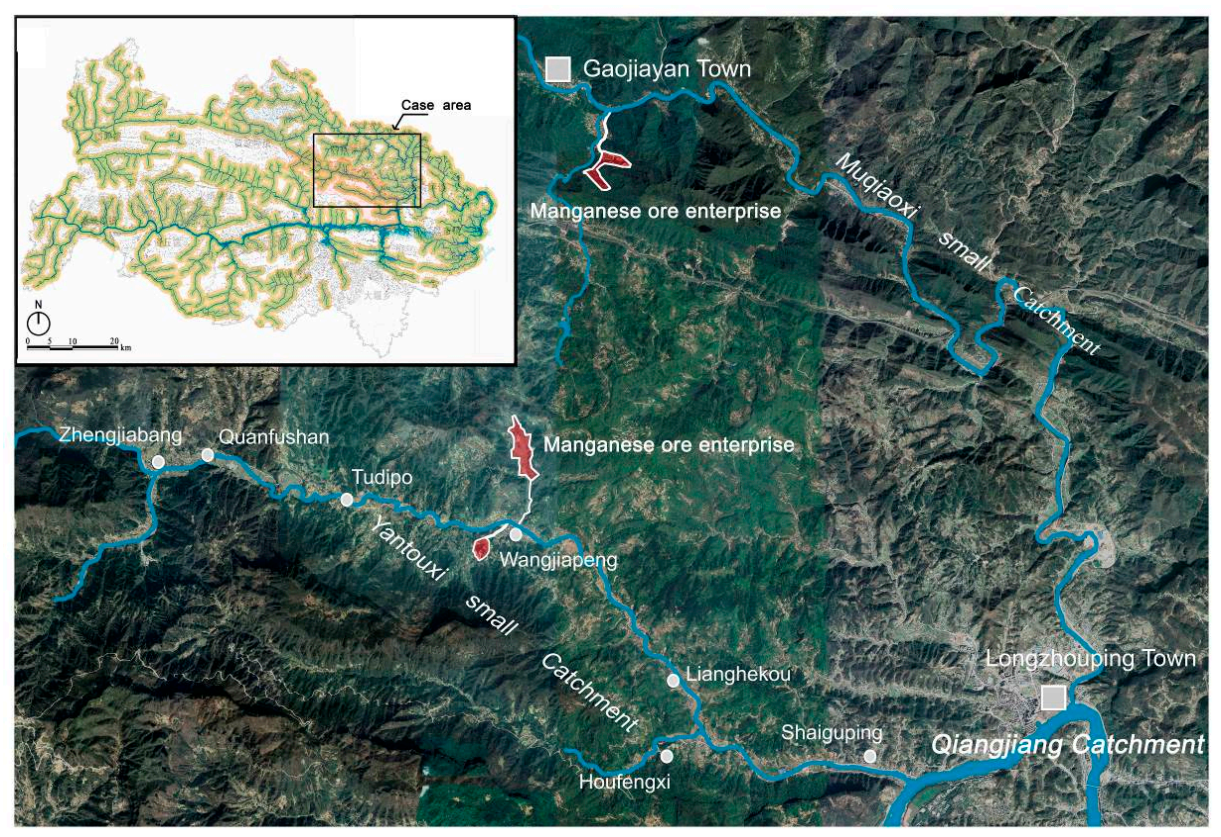

Figure 6. The influence of manganese mineral resource exploitation in the Yantouxi (YTX) small catchment. Figure source: drawn by authors.

Table 2. Case area fieldwork study design.

\begin{tabular}{cccccccccc}
\hline \multirow{2}{*}{$\begin{array}{c}\text { Small } \\
\text { Catchment } \\
\text { Name }\end{array}$} & $\begin{array}{c}\text { Population } \\
\text { Size }\end{array}$ & $\begin{array}{c}\text { Village } \\
\text { (Household) }\end{array}$ & Number & & $\begin{array}{c}\text { Structured } \\
\text { Interview }\end{array}$ & & \multicolumn{3}{c}{ Semi-Structured Interview } \\
\cline { 5 - 10 } & & $\begin{array}{c}\text { Valid } \\
\text { Questionnaires }\end{array}$ & $\begin{array}{c}\text { Poor } \\
\text { Household }\end{array}$ & $\begin{array}{c}\text { Common } \\
\text { Household }\end{array}$ & Elite & Cadre & $\begin{array}{c}\text { Developers } \\
\text { Agency }\end{array}$ & $\begin{array}{c}\text { Government } \\
\text { Official }\end{array}$ \\
\hline YTX & 5071 & 7 & 512 & 17 & 12 & 3 & 18 & 4 & 8 \\
MS & 4667 & 9 & 483 & 7 & 21 & 5 & 13 & 2 & 11 \\
\hline
\end{tabular}




\subsection{Fragmentation of Property Rights Resulting from the Single-Center Governance}

The fragmentation of farmland and the scattered settlement reflect the fact that rural life in mountainous areas has also exacerbated the organizational dilemma of manpower, resources, and capital in the revitalization of rural industries [30,36], resulting in damage to the regional functions of rural areas. Fragmentation of land use has strong externalities and requires effective collective action among farmers to internalize the externalities of agricultural land use into the benefit of the organization [37]. Spatial governance for "anti-fragmentation" is an important way for poor mountainous areas to eliminate public crisis. The literature has pointed out that the diversity of land resource attributes, spatial attributes, and utilization attributes together determines the complexity of spatial governance in mountainous areas. Among them, resource attributes will greatly affect governance effectiveness. In the WMA, natural conditions such as landform, geology, hydrology, soil quality, and climate determine the types of crops and their resource value attributes. In addition, the form of land ownership, infrastructure conditions, and traffic accessibility also affect the utilization properties of resources. The attribution of differentiated resources determines the effect of rural governance logic under the influence of a multi-ministerial "project system". Due to the property rights system, the property rights of small catchments are mostly fragmented into "state-owned property rights" and "collective property rights" [38]. Town governments or village committees have absolute power to control resources and ignore "adjacent rights", resulting in common resources in catchment areas becoming "commons" open to all due to the lack of governance capabilities and the willingness to maintain common property rights. Therefore, it is necessary to comprehensively consider the attributes of rural spatial resources and their cross-border governance modes to promote the spatial governance of small catchments.

At present, the governance logic of "betting on the strong" in the resource allocation of multiple ministries and commissions plays an obvious role in the multi-level government system of China [39]. Rural resource gaps are currently mostly realized through "running projects" by grassroot projects, which weakens the enthusiasm of local governments to cooperate in cross-border public affairs. In the YTX catchment, the "fragmented" collective property rights support the development process of different types of tourism projects (Table 3), including the construction of national, provincial, and municipal scenic spots, and rural tourism projects led by general, social, capital, and village collectives; on the one hand, the fragmented development method based on tourism land has caused problems such as inefficiency and duplication of tourism functions, and fragmentation of tourism ecological space. At the same time, the "project system" (Since China adopted the taxsharing system in the mid-1990s, the "project system" has become increasingly prominent as a form of the top-down resource allocation system, and has become an important mechanism for national governance and the implementation of policy tasks overflowing the fiscal field. The "project system" aims to break the shackles of the existing bureaucratic system as represented by the unit system through such ways as special transfer payment of state revenues, so as to mitigate the differentiation effects caused by the market system and to increase investment in people's livelihood and public services.) of the top-down administration system has increased the competitiveness of local governments in pursuing their respective goals (see Figure 7). Especially when facing the reality of a lack of financial capital, most local governments do not have the ability to plan, develop, manage, and operate in a unified way. As a result, some project developments are led by market capital, but developers often choose superior resources in the region, and the tourism projects with a short investment return period and good prospects for land appreciation are prefered, which intensifies the dilemma of the spatial governance of ecological human settlement units in the WMA. 
Table 3. Poverty incidence of different geographic space types in the YTX catchment.

\begin{tabular}{cccccc}
\hline Geographic Types & $\begin{array}{c}\text { Village Team } \\
\text { Number }\end{array}$ & $\begin{array}{c}\text { Poor Households } \\
\text { Number }\end{array}$ & Poverty Incidence & $\begin{array}{c}\text { Number of Poor } \\
\text { People }\end{array}$ & $\begin{array}{c}\text { Households } \\
\text { Number in } \\
\text { Village Teams }\end{array}$ \\
\hline River valley area & 26 & 468 & $15.3 \%$ & 1290 & 3056 \\
Middle mountain area & 19 & 296 & $21.6 \%$ & 936 & 1368 \\
High mountain area & 10 & 184 & $25.8 \%$ & 596 & 714 \\
Total & 55 & 948 & $18.5 \%$ & 2822 & 5138 \\
\hline
\end{tabular}

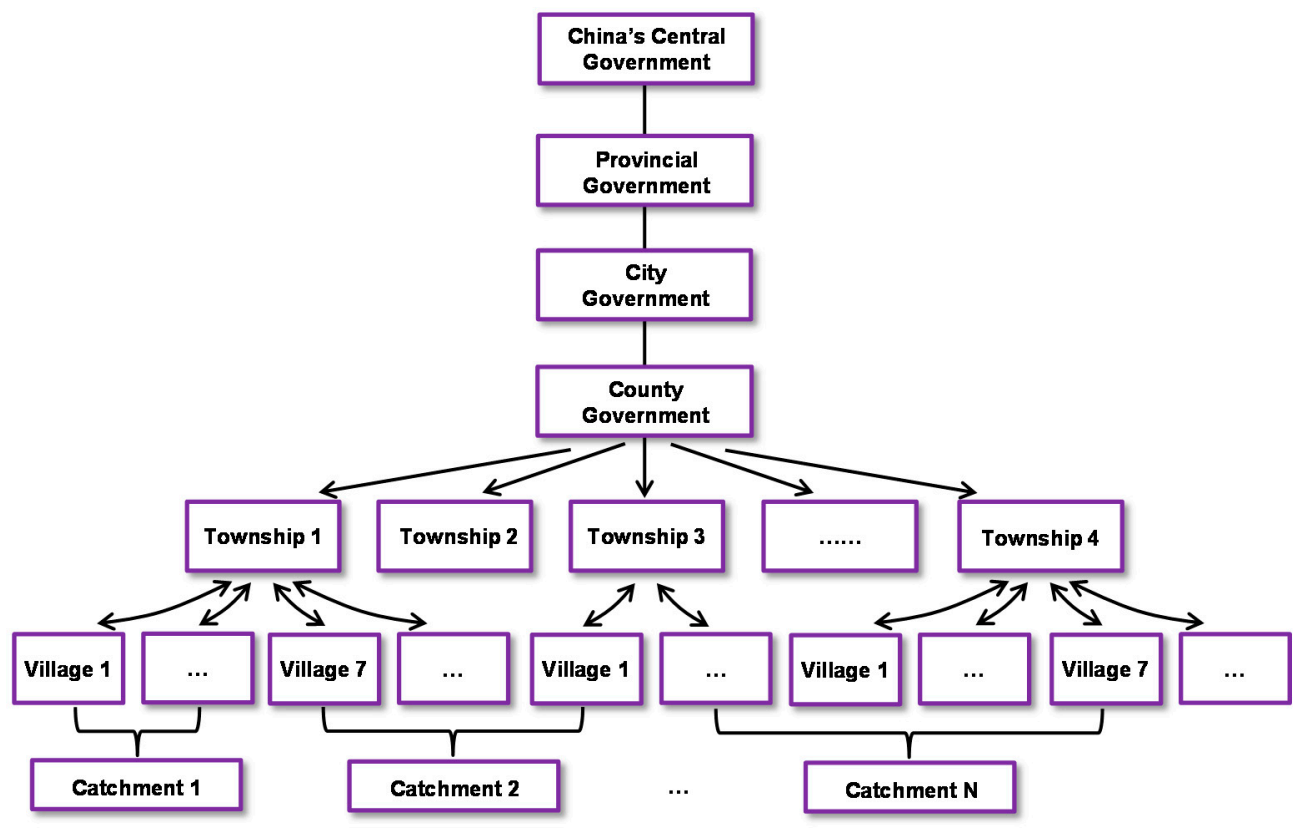

Figure 7. The catchment units embedded into China's governance hierarchy in mountainous areas. Figure source: reproduced by authors, referencing Rogers, S., 2014 (P.199) [40].

\section{Benefits of Small Catchment to Sustainable Spatial Governance in WMA}

\subsection{Extraction of Resource Endowment to Improve the Ecological Function of Rural Settlements}

In WMA, ethnic minorities are diverse, with rich settlement patterns and fragile natural ecology, presenting the characteristics of a typical cultural and ecological community. The livelihood of local villagers is highly adaptable to the human resources and ecological environment (water resources, vegetation, industrial structure, etc.). The difference among these villages reflects the different use efficiency of human resourcesto natural resources. Only by breaking out of the existing poor people's lifestyle and socioeconomic development mode can the long-term solidified and closed social and economic system of China in ethnic mountainous areas be broken, realizing the sustainable development of vulnerable agricultural areas [41].

The Moshi (MS) catchment involves nine administrative villages. Affected by karst landforms and "rocky desertification" geological conditions, the ecological spatial characteristics of rural settlements and the agricultural industry structures are closely related to geology, hydrology, climate, mountains and forests, and traffic conditions. It is found that rural industrial projects dominated by "top-down" poverty alleviation are mostly affected by the "project acceptance inspection" of administrative units in recent years, excessive pursuit of land economic output and economies of scale, and ignoring the local resource endowment structure. With the increasingly stringent standards for rural ecological and environmental protection, the development of rural industries in mountainous areas should be based on sustainable ecological management of catchments, such as the integration of "epidemic prevention management unit" and the regional "ecological environment 
monitoring unit" for pig breeding in small catchment units (Figure 8), scientifically control the scale of pig breeding, reduce the risk of diseases in farmed agricultural products and ensure food safety.The main pieces of evidence and governance experience include: (1) Based on the endowment of ecological planting and breeding resources in mountainous areas, by improving the traditional planting and breeding models and the relationship between planting and breeding, we will promote the reorganization of the ecological space of human settlements and the improvement of industrial functions. For example, the differentiated planting environment types and land carrying capacity of small watershed villages determine the layout and scale of the pig breeding industry. (2) According to the characteristics of regional resource endowments and market supply relationships, there is a need to activate spatial elements (manpower, capital, and technology) and expand industrial space forms (such as ecological planting and breeding units, special deep-processing areas, green courtyard economy) to promote cross-industry integration. For example, to promote the integrated development of ecological planting and breeding in a small area, the Moshi small catchment has formed an ecological circulation breeding mode of "Broussonetia papyrifera and pigs supporting each other", and established the poverty alleviation industry chain of "Broussonetia papyrifera planting-feed processing-ecological breeding-pig sales" (Figure 8). (3) Through the comprehensive improvement of mountains, water, forests, fields, and roads in small catchments, promoting the overall planning of catchment resources and improving land use efficiency and labor productivity on the basis of ensuring the stability of agricultural pillar industries, the quality of rural settlements and service features in the small catchment will be benefited. For example, through a number of characteristic plantings, such as yew, camellia, tea plum, sweet plum, etc., the micro-environment of traditional planting units is improved and enhances the resilience and wind resistance of the local agricultural industry. On the whole, the characteristic of resource structure in poor areas is a serious lack of capital. Only through the strategy of comparative advantage can the relative abundance of capital in resource endowments be increased; meanwhile, the structure of resource endowments and the linkage development of surrounding villages will be promoted. Finally, the coupling of industrial functions in the catchment and the ecological spatial relationship between stakeholders and rural settlements can be formed.

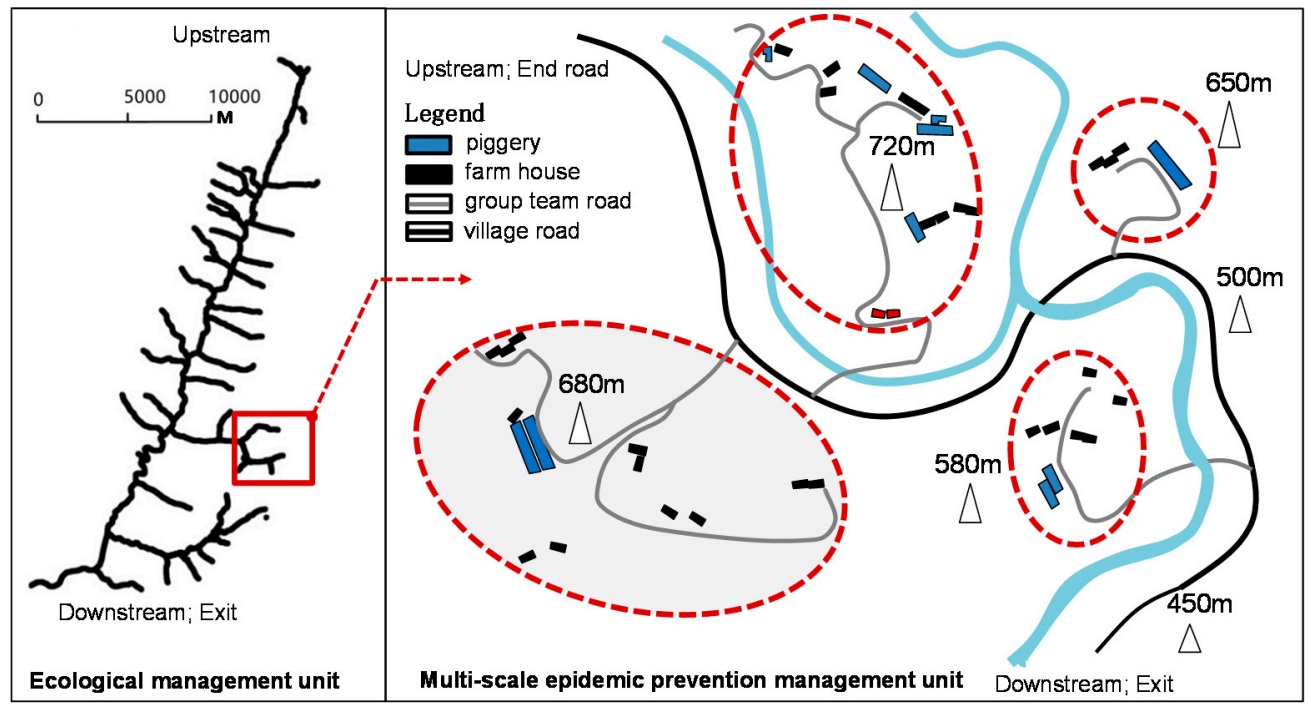

Figure 8. Ecological management unit and breeding epidemic prevention management unit in MS small catchment. Figure source: drawn by the author.

\subsection{Enhancing the Vertical Spatial Productivity to Empower Poverty-stricken Groups}

In most developing countries, poverty tends to be spatially agglomerated. Some extremely poor areas are often in very unfavorable geographical conditions, such as geog- 
raphy, soil, topography, climate, location, etc. [40], which is summarized as a "geographic poverty trap" [42]. Once falling into this trap, it is not enough to rely on the support of macro-poverty alleviation policies; instead, it is necessary to pay attention to regional advantages and localize the macro-policies to the local natural and human environment [43].

The Yantouxi small catchment is located in Longzhouping Town, CTAC, which is a model township for tourism; it involves seven administrative villages, with elevation differences ranging from ninety meters to one-hundred sixty-eight meters. It is adjacent to the national 5A Qingjiang Gallery Scenic Spot, including a national 4A scenic spot and many other local attractions. Affected by the development of global tourism and targeted poverty alleviation policies, the characteristics of the spatial reorganization of the ecological human settlements in the Yantouxi catchment in the past five years are obvious. According to the third national land survey data in 2019, 56\% of the county's rural settlements ( $48 \%$ in the second adjustment data in 2013) are distributed within five hundred meters on both sides of the basin. Affected by the differences in vertical spatial productivity in mountainous areas, population clusters show the characteristics of spatial behavior differentiation of "the poor run to the mountains and the rich cluster in the bays". (This sentence is a proverb circulated by local villagers in mountainous areas. It means that villagers with a poverty mindset are willing to hide in high mountain areas, and villagers with a wealth mindset are willing to go to the mouth of the catchment, the low-lying terrain, and the exit with convenient transportation.) The overall analysis results show that the new round of rural households in mountainous areas tends to gather in central village communities and along important transportation routes; at the same time, in the face of government-led ecological immigration (ecomigration) anti-poverty policy, the actual relocation of rural households is not strong except in high mountain areas. The infrastructure conditions are regressive, but the development of rural tourism in the whole region has changed the relationship between people and land on the mountain and at the foot of the mountain, and has reduced the transaction cost of resources in the high mountain areas. Therefore, close to $30 \%$ of the farmers in the Yantouxi small catchment are still willing to live in high-altitude (above nine hundred meters) areas (Figure 9). How can the economic and geographical characteristics of the catchment and resource endowment structure be used to enhance the vertical spatial value and expand the niche of the villages in the marginal area? How can we empower poverty-stricken mountain groups through the design of the land system, increased spatial productivity, and the promoted benefits of contiguous poverty alleviation in the catchment? For example, improving the land use efficiency of mountain forests after population migration is an important measure to improve the effect of ecological poverty alleviation. Local governance experience mainly includes: (1) The overall development of the small catchment helps to enhance the value and functional characteristics of the mountain resource system, and integrates poor groups in marginal areas into the framework design of the benefit sharing mechanism, such as the reconstruction and rebuilding of the benefit distribution mechanism between the people on the mountain and the people at the foot of the mountain from public institution design. Additionally, through the assistance mode of "cooperative + poor households", the mountain and forest land of poor households in high mountainous areas will not be neglected and the problem of nearby employment of poor households is also solved. (2) Using the ecological gradient characteristics of the catchment, optimizing the spatial layout of rural resources, and enhancing spatial productivity in mountainous areas. For example, with the help of high-quality upstream ecological conditions and geological landscape to attract investment in the overall development of the catchment and landscape infrastructure, the coordinated development of villages in or around scenic areas will be promoted through "jointly built scenic spots and the villages". (3) Using the differences in ecological environment such as altitude, soil $\mathrm{pH}$, temperature, and light environment to enhance the economic value of crops, and to help deeply impoverished households in high mountainous areas form a source of income (Figure 10). For example, combining advanced photovoltaic technology and agricultural production technology to create a 
"Photovoltaic + agriculture" compound agricultural system. At the same time, it adopts a variety of operation modes such as distributed users, village collectives, and large-scale photovoltaic poverty alleviation in joint villages, and coordinates the relationship between the government, market, village collectives, and poor households; this utilizes idle areas such as roofs of poor households and barren hills in high mountainous areas to develop the photovoltaic industry, implement local policies to empower poor households, and increase the economic benefits of farmers.
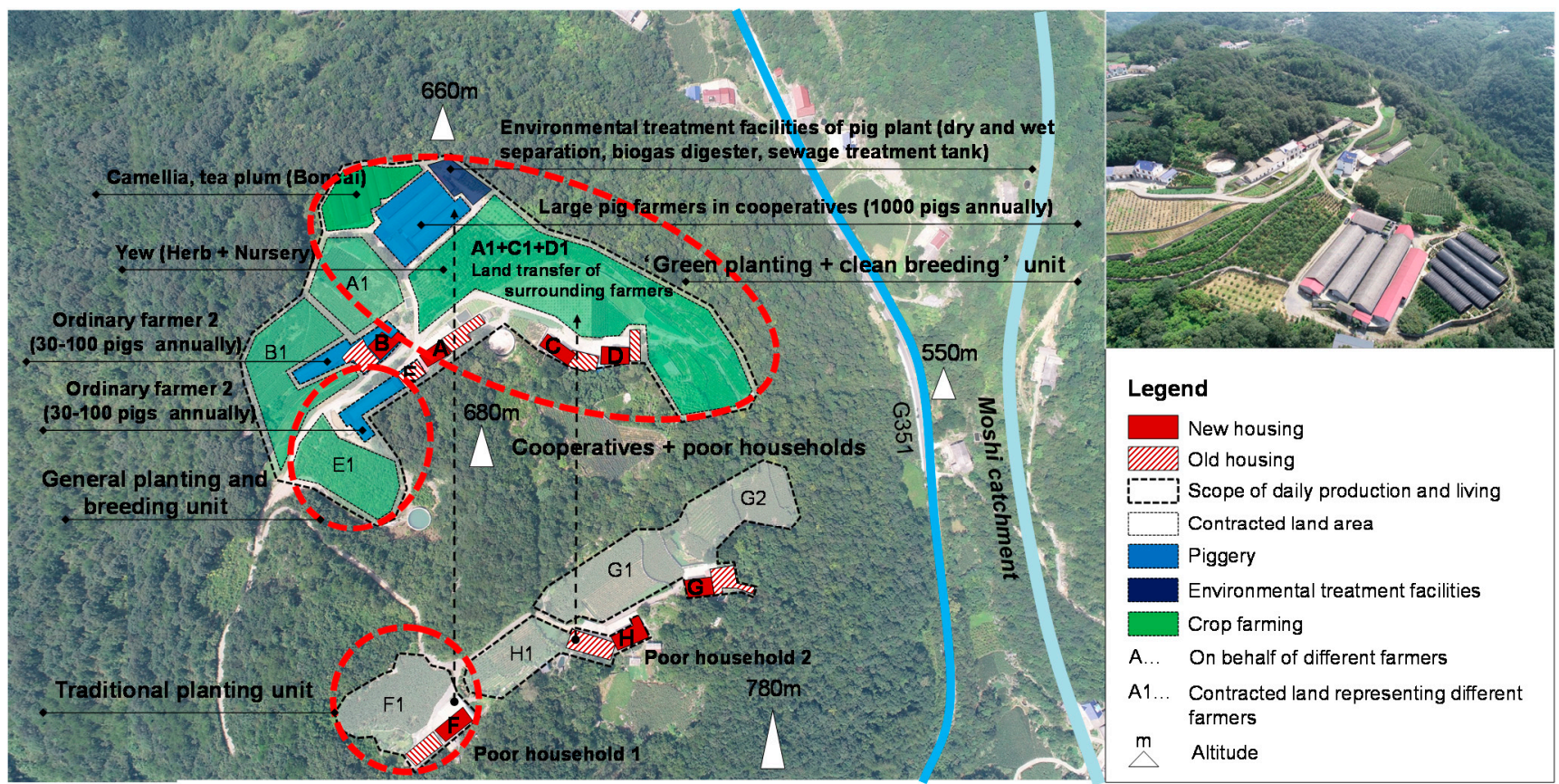

Figure 9. The sustainable driving effect of the cooperative "green planting + ecological breeding" on the poor households. Figure source: drawn by the author.
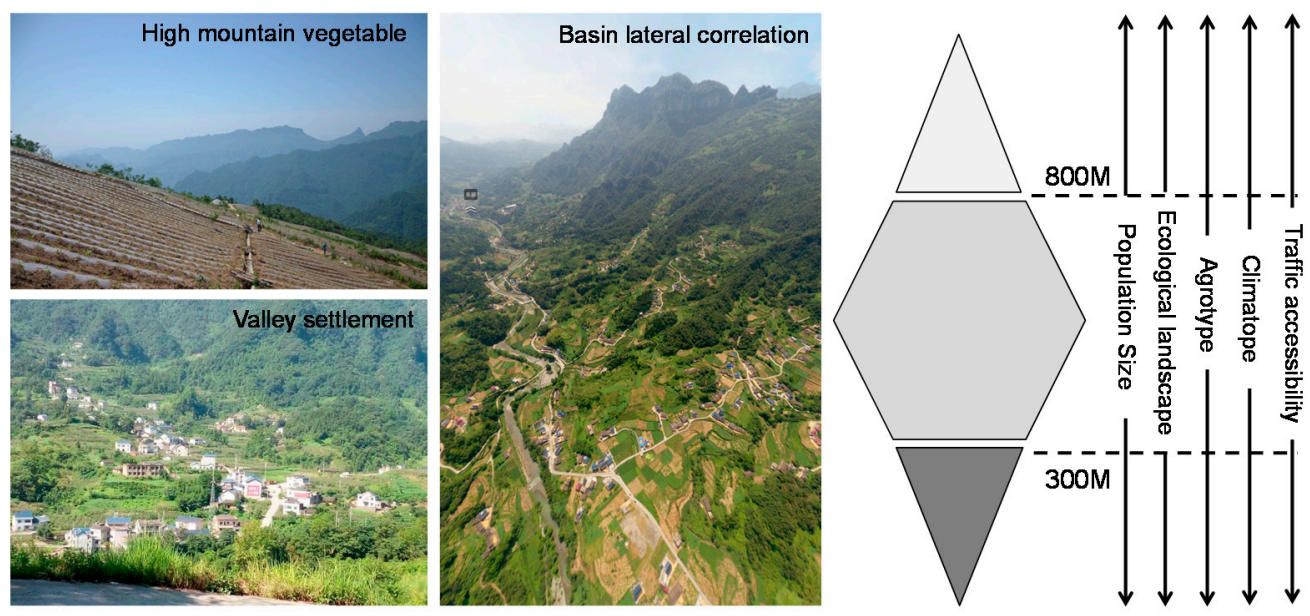

Figure 10. Difference of vertical spatial gradient in mountainous areas and its influencing factors. Figure source: reproduced by the author.

\subsection{Promoting Elastic Scale Reorganization to Appeal Multi-Center Governance}

In mountainous areas, widespread diseconomies of scale have increased external transaction costs, resulting in fragmented and narrow local markets and low levels of industrial structure. In return, low-quality industrial structure will exacerbate environmental pollution and further aggravate poverty [44]. The investigation found that the decline of 
the agricultural industry in mountainous areas is directly related to the fragmentation of farmland property rights and the unclear property rights. The "fragmentation" of land scale and property rights increases transportation and agricultural production costs, hindering the development of agricultural modernization. Local experts have pointed out that the Tujia minorities in the WMA have a tradition of "being hidden in the mountains but not on the plains". Since China's reform and opening up, the form of land-sharing based on the household contract responsibility system has further aggravated the decentralization of farmland in ethnic mountainous areas. Fragmentation of the business structure increases transaction costs such as rural environmental governance and public service provision [45]. Therefore, moderate scale management of farmland is the realistic requirement for improving the spatial governance ability of ethnic mountainous areas. Specific governance experience includes: (1) The small catchment unit has constructed a multi-sectoral "integrated system" for the supply of rural public goods at the county level, which helps to coordinate the project priorities of the county's land and resources bureau, hydrological bureau, finance bureau, tourism and cultural bureau, transportation bureau, etc., and enhance the spatial governance benefits of multiple ministries and commissions under the governance logic of the "project system". Especially in the context of a weak village collective economy, the small catchment unit breaks administrative boundaries and avoids disorderly competition between villages or the involution of governance caused by excessive agglomeration of village resources, weakening the "fragmented" pattern of resource development and the administrative-led single-center governance mode. (2) The social organization of a small catchment is affected by the local historical and geographical conditions, and forms an adjacent governance effect "embedded" in the local governance structure at the informal government level. Villages involved in the small catchment can participate in policy consultation and grassroots decision-making, whether strong or weak, which enables participants, public departments, and local governments to connect through social capital and gain the ability to influence resource allocation and "political leverage" [46]. In China, although there are many difficulties in promoting the spatial governance of small catchments, the construction of such a governance unit that crosses the boundaries of traditional community governance provides a "social capital linkage" with a valuable relationship [47] that helps increase local understanding and social cohesion. (3) Multi-scale spatial reorganization based on small catchment units can help balance the differences in endowments between villages in land resources, human capital, and social capital, and determine more effective types of rural public goods and consumption scale. Figure 11 shows that close social connections and frequent resource exchanges within small catchment units are conducive to improving the overall benefits of village resource utilization. They construct a linkage development mode that responds to the multi-scale governance needs of small catchments, such as from "cooperative + farmer" to "company + cooperative + village committee" and then to "urban investment company + scenic spot + village committee" development mode selection, which will transform rural areas and possibly even the cross-border, cross-over, and intensive allocation of urban resources to overcome the interest drive of local governments to act independently. 


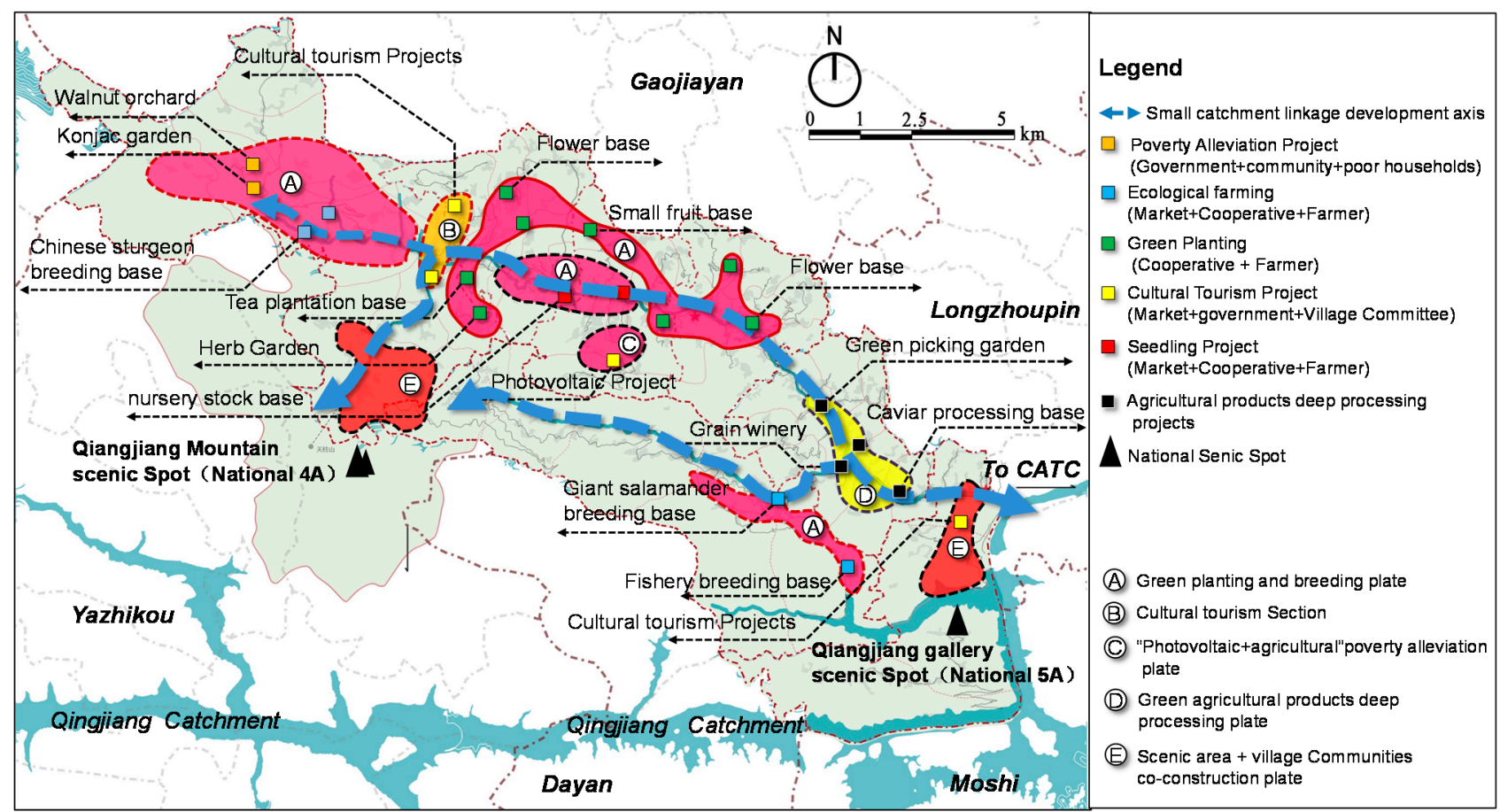

Figure 11. Multi-scale spatial reorganization of local resource elements under the participation of multi-center interest bodies. Figure source: drawn by the authors.

\section{Conclusions}

Governance constraints on the development of mountainous areas remain the bottleneck of China's poverty alleviation and the building of a moderately prosperous society proposed in all respects. The development of mountainous areas needs to make better use of the comparative and latecomer advantages of the rich regional ecological and cultural resources. However, constrained by the solidified administrative management unit in rural China, especially the "project system" governance formed in the top-down logic of the "poverty alleviation era", it is particularly clear that the focus is on the single-center governance mode and the "betting on the strong" on resource allocation in mountainous rural areas. Therefore, how can the combination of "top-down + bottom-up" modes and the construction of multi-center and holistic spatial governance in mountainous areas be promoted to face rural governance innovation in mountainous areas? The small catchment is the basic spatial unit of industrial development and rural settlement activities, and serves as the functional carrier of regional spatial governance and rural revitalization. In-depth analysis of the benefits of small catchment for sustainable governance provides an important research perspective for solving the theoretical and practical problems of mountainous rural revitalization on a microscale. The following are some preliminary findings.

First, the cognition of catchment governance in rural China is moving from hydrology to society, and has shifted from theoretical thinking to practical needs [48,49]. In China, rural governance based on administrative units has constructed a historical and geographical basis for rural social stability, and has also provided institutional support for the sinking of state power in the "top-down" manner and precise policy implementation. Faced with the restriction of the single-center model of rural governance and the endogenous development demands of "bottom-up" in grassroots systems, the national, provincial, city, county, town (township), and village levels have begun to form awareness of catchment governance and through institutional innovation, policy loosening, market model innovation, industrial linkage development, and co-construction of infrastructure, promoting the overall development of the catchment. Although river leaders have been widely implemented in rural 
China [50], the system to promote the comprehensive management of small catchments is still insufficient. In general, the promotion of small catchment governance provides a major reform impetus for rural governance innovation and triggers multidisciplinary theoretical thinking.

Secondly, the public nature of the ecological environment of the catchment has constructed the basis of spatial governance for ecological protection and industrial revitalization in mountainous areas. Compared with the collective economic thinking or single-center development demands under the traditional administrative unit, the catchment perspective shows more demands for overall interests, such as demands for poverty alleviation in fringe areas. They are more concerned about the effect of some demonstration villages and the economic driving effect on surrounding areas. Specifically, the grassroots government initiated the overall development plan, and generally listed the publicity of the catchment as a priority for development. At the same time, it is an important goal to handle the relationship between the central development area and poverty-stricken groups.

Finally, facing the traditional development constraints in mountainous areas, the promotion of cross-border governance of the catchment units requires the establishment of a "top-down" system designed by the central government; at the same time, it also needs to respect the historical and geographical basis of mountainous rural communities based on features of local ecological and cultural resources, tap the two-way demand of endogenous linkage development and governance innovation, and promote the comprehensive management of small catchment spaces in accordance with local conditions. In the case study, experience in MS shows that traditional agricultural planting and breeding environments in mountainous areas have typical characteristics of regional ecosystems, deeply revealing the "ecology, society, economy" interaction mechanism in the human ecological settlements in mountainous areas, and rationally guiding the optimal allocation of agricultural resource elements to enhance the overall governance effect of the small catchment unit. In addition, the YTX case shows that local governments are more inclined to invest a large amount of public financial resources and projects in the catchment through market agents (urban investment companies) in order to obtain the legal power to determine the legality of investment in fixed assets across collective property rights; however, local governments are likely to ignore some practical situations, that is, different collective property rights in YTX actually face diversified market choices. Therefore, what role the local government and benign market capital play in the different rural development stages, and what kind of interactive cooperation relationship they build, determine the possibility of the overall governance of the catchments and the effect of "anti-fragmentation" governance in the WMA.

However, the study also has some limitations. The investigation of this research is limited to the WMA of Western Hubei. The selected cases have outstanding resource endowments and active social capital in the region. They have the advantages of linkage development needs, and have received multi-level government policy and financial support in terms of project practice. In the two cases selected in CTAC, benefiting from the local historical and geographical environment, traffic conditions, and the foundation of rural grassroots governance, the development of the small catchment presents many cross-border public affairs governance and overall interest needs, but this is not true for all cases. In order to fully understand the benefits of small catchments for rural spatial governance in mountainous counties, more case studies at different development stages, different functional types, and different scales should be tracked and investigated. This will help to deepen our cognition of the ecological, economic, and social organization mechanisms behind the governance of small catchments, and discover the meaning of the governance of catchments and the practice's direction in rural China.

Author Contributions: This paper is the output of concerted efforts from all co-authors. Conceptualization, J.Q. and M.C.; data curation, J.Q.; formal analysis, J.Q., M.C., L.H. and X.L.; investigation, J.Q.; methodology, J.Q., L.H. and M.C.; resources, L.H.; visualization, J.Q.; writing-original draft, 
J.Q.; writing—review and editing, J.Q.; All authors have read and agreed to the published version of the manuscript.

Funding: This research received funding from the National Science Foundation of China (Grant No.: 52008179), National Natural Science Foundation of China (Grant No.: 52008179), China Posdoctoral Science Foundation (Grant No.: 2019M662628), and CSC (China Scholarship Council) A1 Foundation (Grant No.: 201706160059) for financial support.

Acknowledgments: The research is supported by the Research and Training Center for Rural Revitalization of Ethnic Minorities, Huazhong University of Sci. \& Tec., and the Geography department of Durham University, UK. A draft version of this paper was presented at the 2018 International Conference on China Urban Development: Urban Transformation and 'New Style' Urbanisation in China, Glasgow, UK. We also gratefully acknowledge the National Natural Science Foundation of China (52008179), China Postdoctoral Science Foundation (2019M662628), and CSC (China Scholarship Council) A1 Foundation (201706160059) for financial support.

Conflicts of Interest: The authors declare no conflict of interest.

\section{References}

1. Lampe, K.J. Rural development in mountainous areas: Why progress is so difficult. Mt. Res. Dev. 1983, 3, 125-129. [CrossRef]

2. Douglas, D.J. Rural regional development planning: Governance and other challenges in the new EU. Studia Reg. 2006, 18, 112-132.

3. Taylor, P.; Fransman, J. Learning and Teaching Participation: Exploring the Role of Higher Learning Institutions as Agents of Development and Social Change; Working Paper Series, 219; IDS: Brighton, UK, 2004.

4. Research for Regi Committee-Cohesion in Mountainous Regions of the EU. Available online: http://www.fao.org/familyfarming/detail/zh/c/410385/ (accessed on 9 May 2018).

5. Allen, N.J.; Gregory, D.; Urry, J. Social relations and spatial structure. Man 1985, 22, 197. [CrossRef]

6. Xin, W.; Peng, C. A Study of the Time-Space Evolution Characteristics of Urban-Rural Integration Development in a Mountainous Area Based on ESDA-GIS: The Case of the Qinling-Daba Mountains in China. Sustainability 2016, 8, 1085.

7. Chen, J.H. Study on economic development model and approach of Beijing's mountainous valley areas. Procedia Environ. Sci. 2011, 10, 198-202. [CrossRef]

8. De Groot, R.S.; Alkemade, R.; Braat, L.; Hein, L.; Willemen, L. Challenges in integrating the concept of ecosystem services and values in landscape planning, management and decision making. Ecol. Complex. 2010, 7, 260-272. [CrossRef]

9. Fenemor, A.; Phillips, C.; Allen, W.; Young, R.; Harmsworth, G.; Bowden, B.; Basher, L.; Gillespie, P.; Kilvington, M.; Davies-Colley, R.; et al. Integrated catchment management-Interweaving social process and science knowledge. N. Z. J. Mar. Freshw. Res. 2011, 45, 313-331. [CrossRef]

10. Allan, D.; Erickson, D.; Fay, J. The influence of catchment land use on stream integrity across multiple spatial scales. Freshw. Biol. 1997, 37, 149-161. [CrossRef]

11. Woods, M. Rural Geography: Processes, Responses and Experiences in Rural Restructuring; Sage: Newcastle upon Tyne, UK, 2004; pp. 22-28.

12. Long, H.L. Land consolidation: An indispensable way of spatial restructuring in rural China. J. Geogr. Sci. 2014, 24, 211-225. [CrossRef]

13. Long, H.L.; Liu, Y.S. A brief background to rural restructuring in China: A forthcoming special issue of Journal of Rural Studies. J. Geogr. Sci. 2015, 25, 1279-1280. [CrossRef]

14. Long, H.L.; Liu, Y.S. Rural restructuring in China. J. Rural Stud. 2016, 47, 387-391. [CrossRef]

15. Finco, M.V.A. Poverty-environment trap: A non linear probit model applied to rural areas in the North of Brazil. Am. Eurasian J. Agric. Environ. Sci. 2009, 5, 533-539.

16. Zhang, Y.F.; Jia, D.M.; Tan, J.; Zhang, H.Y.; Song, S.Y.; Sun, R.F. The spatial structure of valley economy development in the mountainous areas of Beijing. Acta Geogr. Sin. 2009, 10, 1231-1242.

17. Liu, P.L.; Liu, C.L. Typical modes of valley economy and its enlightenment on protecting ancient villages in the mountainous areas of beijing. Econ. Geogr. 2010, 12, 1944-1949.

18. He, Y.; Wang, Z. Study on the suitable model of human settlement-The concept of "Basic Human Ecological Unit". New Archit. 2005, 4, 97.

19. Liu, H. The Regional Small Catchment Units of Human Settlements and the Security Models on the Loess Plateau-Research from Analyzing of the Landscape Pattern. Ph.D. Thesis, Xi'an University of Architecture \& Technology, Xi'an, China, 2005; pp. 14-18.

20. Wang, D.L.; Shi, Y. Chinese catchment governance in the perspective of trans-regional governance. New Horiz. 2013, 5, 51-54.

21. Zhao, Y.X.; Guo, S.M. Patterns of urban circular agriculture based on agricultural industries-A case study of Fangshan District of Beijing City. Chin. J. Eco-Agric. 2008, 4, 971-975.

22. Yu, H.Q.; Zhang, X.S.; Huang, X.D. On the development of comprehensive tourism in mountainous rural community under the view of small catchment: A case study of Majiang county. J. Huaihua Univ. 2019, 38, 42-45. 
23. Wang, Z.P. Comparative analysis of village ecosystem in different geomorphologic gegions. Rural Ecol. Environ. 1993, 9, 11-15.

24. Huang, A.B. On environmental cooperation governance towards post-industrial society. Soc. Sci. 2019, 5, 3-10.

25. Chen, M.X.; Tang, Z.P.; Liu, W.D.; Lu, D.D.; Zhang, Y.F. The "valley economy" model of regional development: A case study of mountain areas in Beijing, northern China. J. Mt. Sci. 2014, 11, 1372-1382.

26. Tian, C.H.; Fang, L. Impact of rural land rental market on land redistribution under HRS. J. Nanjing Agric. Univ. 2014, 14, 66-74.

27. Xiong, Z.X. Enriching opportunities for the people, reducing poverty and crowding out effects: A study of the survey samples of 18 villages in Wuling area. J. Yunnan Minzu Univ. 2018, 35, 77-88.

28. Long, Y.S.; Wu, X.L. Entering Wuling mountain area. Ethn. Forum 2011, 9, 4-5.

29. Li, P.L. Focusing on addressing the "weak links" of people's livelihood in building a moderately prosperous society in all respects. Truth Seek. 2015, 7, 26-28.

30. Li, J.J. On Selection of Leading Industries in Ethnic Areas Taking Prefectures and Counties of Minority Nationalities in Wuling Mountainous Areas as an Example. J. South-Cent. Univ. Natl. 2005, 2, 60-64.

31. China Government Website. Available online: http:/ / zcfgs.seac.gov.cn/art/2017/7/6/art_9916_284073.html (accessed on 3 July 2020).

32. Ying, Y.C.; Shen, Q.J.; Wang, Y.Q.; Zhang, D.L.S.; Deng, T.J.; Ling, M.; Zhang, M. From targeted poverty alleviation to rural revitalization:study and practicing rural precise planning in eighteen-cave village. Urban Plan. Forum 2019, 2, 99-108.

33. Xi, J.C.; Zhang, N. An analysis of the sustainable livelihood of tourism households: A case study in Gougezhuang village, yesanpo tourism area. Tour. Trib. 2016, 31, 65-75.

34. Lin, Y.F.; Cai, F.; Li, Z. Comparative Advantage and Development Strategy-A reinterpretation of the "East Asian Miracle". Chin. Soc. Sci. 1999, 5, 4-20.

35. Ye, M.; Wang, Z.F. Analysis on the influence mechanism of transportation network for the spatial structure of regional tourism: Case of wuling mountain area. Econ. Geogr. 2017, 37, 213-219.

36. Liu, J.; Jin, X.; Xu, W.; Sun, R.; Han, B.; Yang, X.; Gu, Z.; Xu, C.; Sui, X.; Zhou, Y. Influential factors and classification of cultivated land fragmentation, and implications for future land consolidation: A case study of Jiangsu Province in eastern China. Land Use Policy 2019, 88, 1-19. [CrossRef]

37. Wang, H.J. Make the Best Use of Land: A Research on the Use of Fragmented Farmland. Ph.D. Thesis, Huanzhong University of Science and Technology, Wuhan, China, 2016.

38. Tian, L.; Luo, C.H. land share-holding system and land-use in industrialization of countryside: A case study on Shunde. Urban Plan. 2012, 36, 25-31.

39. Rogers, S. Betting on the strong: Local government resource allocation in China's poverty counties. J. Rural Stud. 2014, 36, 197-206. [CrossRef]

40. Minot, N.; Bob, B.; Michael, E. Poverty and Inequality in Vietnam: Spatial Patterns and Geographic Determinants; Research Reports 148; International Food Policy Research Institute: Washington, DC, USA, 2006.

41. Tong, Y.Q.; Long, H.L. Study on sustainable development in the poor areas coupled with vulnerable eco-environment. China Population. Resour. Environ. 2003, 2, 50-54.

42. Jalan, J.; Ravallion, M. Geographic poverty traps? A micro model of consumption growth in rural China. J. Appl. Econom. 2002, 17, 329-346. [CrossRef]

43. Ge, Y.; Yuan, Y.; Hu, S.; Ren, Z.; Wu, Y. Space-time variability analysis of poverty alleviation performance in China's povertystricken areas. Spat. Stat. 2017, 21, 460-474. [CrossRef]

44. An, S.M.; Zhang, S.Q. Environment v.s poverty combining with the degradation of industrial structure in western China. Forecas Ting 2005, 3, 14-18.

45. Tan, S.H.; Qu, F.T.; Nick, H. Analysis on the cause of land fragmentation and its influencing factors. China Rural Surv. 2003, 6, 24-30.

46. Skidmore, P.; Kirsten, B.; Hannah, L. Community Participation. Who Benefits; Joseph Rowntree Foundation: York, UK, 2006.

47. Blake, G.; Diamond, J.; Foot, J.; Gidley, B.; Mayo, M.; Shukra, K.; Yarnit, M. Community Engagement and Community Cohesion; Joseph Rowntree Foundation: York, UK, 2008.

48. Li, Z.K. Philosophical thinking of harness for small catchment. Bull. Soil Water Conserv. 1994, 1, 30-37.

49. Zhang, Z.H. Transboundary cooperation in the catchment governance viewed from the perspective of "macro" collective action theory: Taking zhang river as an example. Nankai J. 2014, 2, 110-117.

50. Chien, S.S.; Hong, D.L. River leaders in China: Party-state hierarchy and transboundary governance. Political Geogr. 2018, 62, 58-67. [CrossRef] 